Shulga O. V. Conservative treatment of the longitudinal flatfeet in children. Journal of Education, Health and Sport. 2021;11(07):298-309. eISSN 2391-8306. DOI http://dx.doi.org/10.12775/JEHS.2021.11.07.028 https://apcz.umk.pl/JEHS/article/view/JEHS.2021.11.07.028

https://zenodo.org/record/5579488

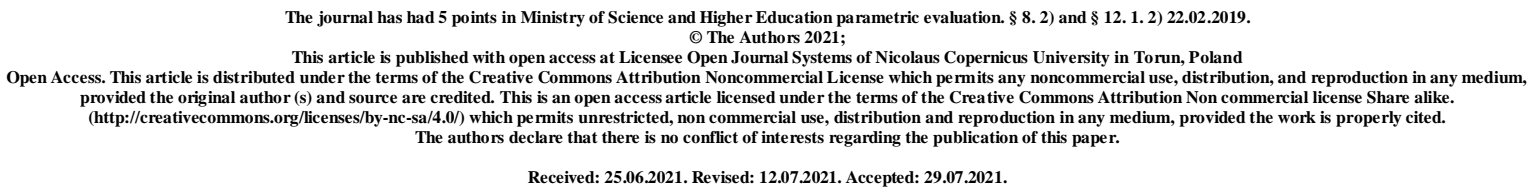

UDC 7.586-007.58-053.2

\title{
Conservative treatment of the longitudinal flatfeet in children
}

\author{
O. V. Shulga
}

\section{P.L. Shupyk National Medical Academy of Postgraduate Education, Kyiv, Ukraine}

O.V. Shulga - orthopedic traumatologist in Bila Tserkva City Hospital №1, postgraduate student of the Pediatric Surgery Department in the P.L. Shupyk National Medical Academy of Postgraduate Education, Kyiv, Ukraine; E-mail Address: belka1205@gmail.com

\section{Abstract}

Introduction. A significant percentage of the musculoskeletal system pathology in children is currently fall on the foot pathology - longitudinal flatfeet, which is not only a medical, but also a social problem. The incidence of this pathology is up to $58 \%$ of the total orthopedic foot pathology.

Traditional methods of treatment and prevention of mild (I- II severity) longitudinal flatfeet (LF), which are known today (massage, physiotherapy exercises, the use of orthopedic devices, electromyostimulation) do not give a significant effect and a stable, long-term result. This makes us look for more effective methods of conservative treatment of LF of the I- II severity degree, which have a pathogenic orientation and physiological effect.

Purpose of the work: to develop the most effective algorithm for the complex conservative treatment of LF, depending on the severity, hemodynamic disorders, deformity options, foot rigidity.

Materials and methods. Conservative treatment was carried out in 62 patients aged $10-18$ years with LF of the I- II severity degree. Depending on the clinical manifestations 
and examination results, the treatment was carried out in two stages. At the first stage, serial casting was used (in the presence of concomitant deformations - silicone pelottes were used).

Results. The results of the two-stage conservative treatment of LF demonstrate the effectiveness of serial casting in combination with the use of silicone pelottes and biostimulators in comparison with traditional methods of foot correction.

Conclusions. Algorithms for conservative treatment of LF were developed, depending on the severity, nature of the deformity, hemodynamic disorders and muscle tone of the lower leg and foot.

\section{Key words: rigid form of longitudinal flatfeet; children; conservative treatment.}

\section{Introduction}

Longitudinal flatfeet is currently not only a medical, but also a social problem. The frequency with which this pathology occurs is up to $58 \%$ of the total orthopedic foot pathology. More than $78 \%$ of longitudinal flatfeet in children is associated with mild and moderate deformity, which requires conservative treatment $[1,2]$.

There are many methods for diagnosing flatfeet [3]. An analysis of clinical observations showed that longitudinal flatfeet (hereinafter referred to as LF) can be combined with various types of deformities in the foot. But the existing classifications of LF do not consider these deformities, which affect the severity of the disease and the choice of treatment method [4].

Traditional methods of treatment and prevention of the I-II severity of LF, which are known today (massage, therapeutic exercises, the use of orthopedic devices, electromyostimulation), do not give a significant effect and a stable, long-term result $[5,6,7]$. One of the known methods of conservative LF treatment with severe pain syndrome is the use of plaster casts [8]. However, serial casting can cause hemodynamic and muscle tone disorders in the lower extremities.

In world practice, biostimulants are used to improve hemodynamics, muscle contractility, soft tissues trophism, but currently, their effect on the muscular-ligamentous apparatus of lower leg and foot with a rigid form of longitudinal flatfeet has not been studied [9].

This forces us to look for more effective methods of conservative treatment of LF, depending on the severity, rigidity in the subtalar joint, hemodynamic disorders, muscle tone of the lower leg and foot. 
Purpose of the work: to develop the most effective algorithm for the complex conservative treatment of RLF, depending on the severity, hemodynamic disorders, deformity options, and the degree of foot mobility.

\section{Materials and methods}

Conservative treatment was carried out in 52 patients (each foot was assessed as a separate clinical case - 104 cases) aged 10-18 years with a rigid form of RLF of the I-II severity degree. Depending on the clinical manifestations and examination results, conservative treatment was carried out in two stages.

At the first stage 31 patients (62 cases) with LF of I-II severity degree, severe clinical manifestations (pain in the feet, low legs, cramps, rapid fatigability) and with associated deformities in different parts of the foot were treated. The control group included 12 patients (24 cases) who underwent complex physiotherapeutic treatment according to traditional pattern (massage, therapeutic exercises, electromyostimulation, correction with soft insoles). The main group included 19 patients (38 cases) and was divided into two subgroups: subgroup A of the main group included 9 patients (18 cases) who underwent serial casting; subgroup B of the main group included 10 patients (20 cases) - they underwent serial casting with the application of silicone pelottes.

Depending on the deformity in different parts of the foot, 8 pathology variants were identified (Table 1) based on the classification, that we developed [4].

Table 1. Distribution of patients (number of cases) depending on the deformity type

\begin{tabular}{|c|c|c|c|c|}
\hline \multirow[t]{2}{*}{ № } & \multirow[t]{2}{*}{ Deformity type } & \multicolumn{3}{|c|}{ Number of cases } \\
\hline & & $\begin{array}{c}\text { Control group } \\
\mathbf{n}=24\end{array}$ & $\begin{array}{c}\text { Main group (A) } \\
n=18\end{array}$ & $\begin{array}{c}\text { Main group (B) } \\
\mathbf{n}=\mathbf{2 0}\end{array}$ \\
\hline 1. & Flattened foot & 4 & 2 & 2 \\
\hline 2. & Flat-valgus foot & 8 & 4 & 6 \\
\hline 3. & $\begin{array}{l}\text { Flat-valgus foot and anterior } \\
\text { adduction }\end{array}$ & 2 & 2 & 2 \\
\hline 4. & $\begin{array}{l}\text { Flat-valgus foot with pronation } \\
\text { and abduction of the forefoot }\end{array}$ & 2 & 2 & 2 \\
\hline 5. & Transversely flattened foot & 2 & 2 & 2 \\
\hline 6. & $\begin{array}{|ll|}\begin{array}{l}\text { Transversely flattened foot } \\
\text { with posterior pronation }\end{array} \\
\end{array}$ & 2 & 2 & 2 \\
\hline 7. & $\begin{array}{l}\text { Transversely flattened foot } \\
\text { with qintus varus and hallux } \\
\text { valgus }\end{array}$ & 2 & 2 & 2 \\
\hline 8. & $\begin{array}{l}\text { Transversely flattened foot } \\
\text { with malleus digitus }\end{array}$ & 2 & 2 & 2 \\
\hline
\end{tabular}


After analyzing the results of the first stage of conservative treatment in the control and main groups, after 12 months of observation, there were disorders of hemodynamics, muscle tone, persistence of pain along the posterior tibial muscle during physical activities. These patients (23) were included in the mane group at the second stage of conservative treatment. To improve the hemodynamics and tone of the lower leg and foot muscles, we used a biogenic stimulator (placenta extract, registration certificate of the Ministry of Health of Ukraine № UA/2465/01/01 dated 30.08.2019).

For comparison, a control group of patients with a rigid form of LF of the I-II severity degree with similar indicators was formed - 21 patients (42 cases). They underwent physiotherapy according to traditional patterns.

During the examination, clinical and radiological diagnostic methods were used. The presence or absence of symptoms (pain in the feet, low legs, cramps, rapid fatigability) made it possible to assess the clinical condition of the lower extremities under static loads.

Pain syndrome was assessed over time using a 5-point scale [10].

- 0 points - no pain syndrome after any activity;

- 1 point - pain syndrome that occurs after a significant activity;

- 2 points - pain syndrome that occurs after short-term activity;

- 3 points - pain syndrome that occurs when the patient begins to walk;

- 4 points - constant pain in the feet, not associated with physical activity.

$\mathrm{X}$-ray examination of the foot was performed with a load in lateral view to assess the scaphoid angle.

The distribution of patients into groups was carried out depending on the applied methods of treatment.

The degree of hemodynamic disorders in the lower extremities was determined using rheovasography (hereinafter - RVG).

To assess the structural condition of the low leg and foot muscles, ultrasonography examination (hereinafter - USG) was performed. Changes in the parameters of the crosssection of the muscles involved in the formation of the medial foot arch were determined.

This study was approved by the Ethics Commission of NMAPE named after P.L. Shupyk (minutes №9, November 6, 2017). The studies were conducted in accordance with the Declaration of Helsinki and the recommendations of the International Council on Harmonization of Good Clinical Practice.

Data are given as the arithmetic average (M) and the standard error of the arithmetic average $(\mathrm{m})$. The null hypothesis of equal variances was rejected at $\mathrm{p} \leq 0.05$. 
Methods of orthopedic, medication and physiotherapy treatment of RLF used to improve the functional condition of the foot

At the first stage of conservative treatment, patients of subgroup A of the main group received orthopedic treatment in four periods, each of which lasted one week.

The first period: using casting positioning, the foot was restored of the flat-valgus foot deformity condition to the physiological position (the angle of correction in one casting session is $10-15^{\circ}$ ), the plaster cast should cover the upper third of the lower leg (Fig. 1).

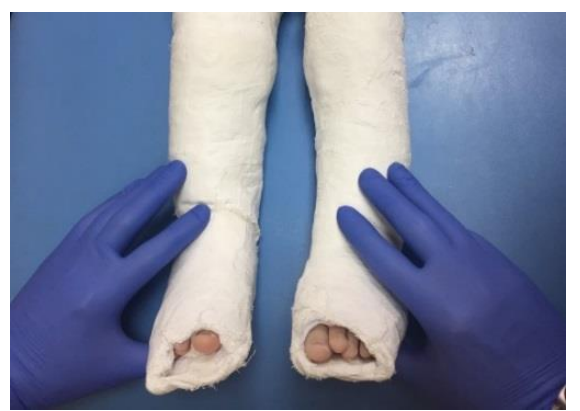

Figure 1. Correction of the flat-valgus foot of the patient $P .10$ years

The second period: after removing the plaster splint, patients underwent complex physiotherapeutic treatment: massage, therapeutic exercise (hereinafter - TE), post-isometric electromyostimulation (hereinafter - EMS) of the lower leg muscles, which form the inner arch of the foot.

The third period: overcorrection - foot was restored into a condition of extreme supination (Fig. 2).

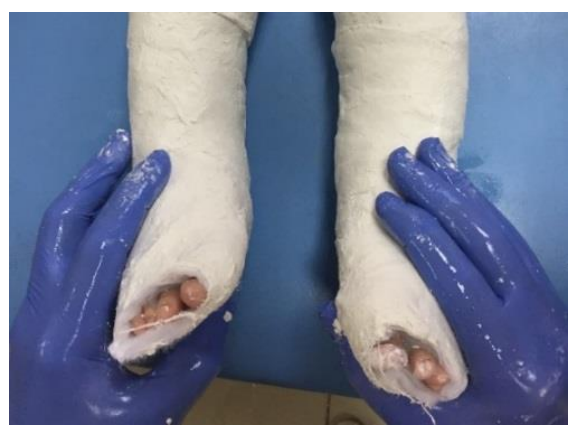

Figure 2. Overcorrection of the flat-valgus foot of patient P. 10 years old

The fourth period: after removing the plaster splint, complex physiotherapeutic treatment and selection of soft individual insoles were carried out.

After each period, active management of the patient using orthopedic devices (crutches, walkers) is recommended. 
Treatment of patients of subgroup B of the main group was carried out using a similar method, plaster casts were combined with silicone pelottes to eliminate associated foot deformities.

In the variants of the flattened and flat-valgus foot, the inner arch is modeled using silicone pelottes (Fig. 3).

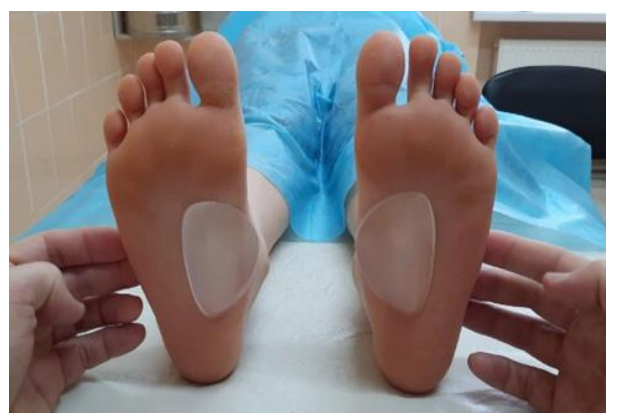

Figure 3. Positioning of the medial arch using silicone pelottes for patient B. 12 years old

During hindfoot pronating, in addition to positioning the arch of the foot, the hindfoot was corrected (Fig. 4).

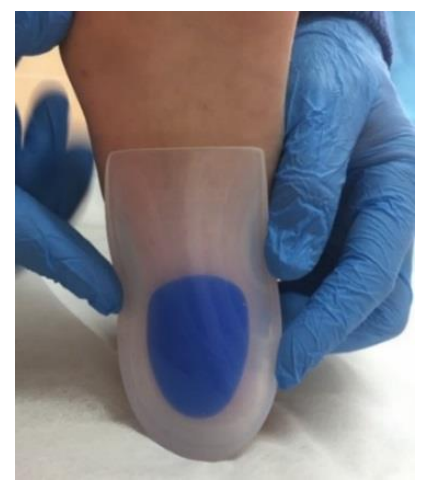

Figure 4. Positioning the hindfoot using silicone pelottes for patient B. 12 years old

In case of transversely flattened foot deformity, the transverse arch was additionally corrected (Fig. 5) 


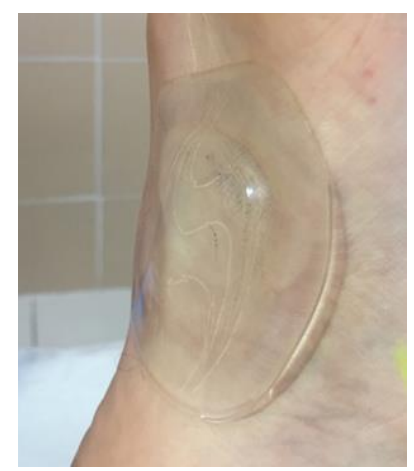

Figure 5. Positioning of the transverse arch using silicone pelottes for patient $D$. 14 years old

In case of longitudinal flatfeet with associated deformation of the fingers (qintus varus, hallux valgus, malleus digitus), the fingers were additionally corrected (Fig. $6 \mathrm{a}, \mathrm{b}$ ).

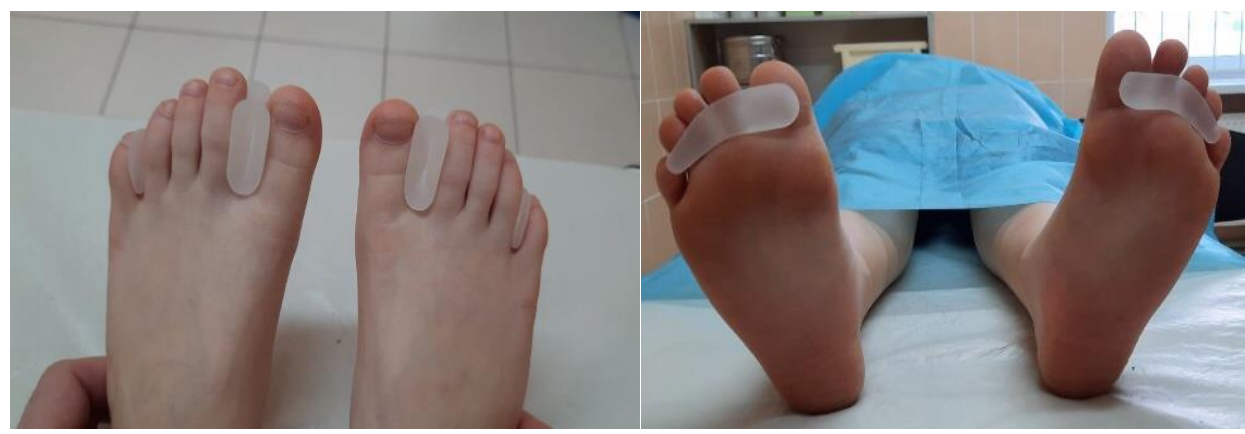

a

б

Figure 6 a,b. Correction of finger deformity using silicone pelottes in patient $B$. 14 years

Due to the use of silicone pelottes in combination with plaster casts, we achieved soft correction of the longitudinal arch and associated foot deformities with minimal disorders of microcirculation.

Patients in the control group with LF of the I-II severity degree received complex physiotherapeutic treatment according to traditional patterns without the use of plaster casts.

At the second stage of conservative treatment, placenta extract was used to improve hemodynamics, muscle tone of the lower leg and foot in the mane group. The medication was injected into the area of tendon-muscle transitions that affect formation of the medial arch: m.tibialis posterior, m.extensor hallucis brevis, m.flexor hallucis brevis, m.abductor hallucis, m.flexor digitorum longus, $\mathrm{m}$. extensor digitorum longus $-0.2 \mathrm{~mm}$ per point. From 5 to 10 points were used daily during 10 days. 30 minutes after the administration of biostimulants, electromyostimulation of the lower leg muscles was carried out with the device "Miorhythm- 
021" in accordance with the characteristics of the identified pain syndrome, the presence of myodystrophy and hemodynamic disorders.

When conducting electromyostimulation, we focused on the quality of muscle contraction - we were looking for the contraction closest to the muscle type, which covers the largest part of the muscle at an optimally selected frequency and minimum current strength. The course of treatment was carried out from 10 to 15 procedures, depending on the severity.

After electromyostimulation, patients underwent manual correction in the form of post-isometric relaxation, as well as classical manual techniques on the lower extremities, therapeutic exercise, and therapeutic massage if there was no pain syndrome.

Patients in the control group used a similar complex physiotherapeutic treatment according to traditional patterns without the use of biostimulants.

\section{Results and discussion}

The dynamics of the clinical picture after the course of orthopedic treatment at the first stage throughout a year made it possible to identify such changes in the main clinical symptoms in patients of both groups.

Analysis of treatment results demonstrates a reduction in clinical symptoms in both groups, reflecting an improvement in the static-dynamic function of the lower extremities (Table 2).

Table 2. Results of clinical trials at the first stage of treatment

\begin{tabular}{|c|c|c|c|c|c|c|c|c|c|c|c|c|c|}
\hline \multirow[t]{3}{*}{ № } & \multirow{3}{*}{$\begin{array}{c}\text { Key } \\
\text { indicators / } \\
\text { observation } \\
\text { period } \\
\text { in months }\end{array}$} & \multicolumn{4}{|c|}{$\begin{array}{c}\text { Control group } \\
n=24\end{array}$} & \multicolumn{4}{|c|}{$\begin{array}{c}\text { Main group (A) } \\
n=18\end{array}$} & \multicolumn{4}{|c|}{$\begin{array}{c}\text { Main group (B) } \\
\mathbf{n}=\mathbf{2 0}\end{array}$} \\
\hline & & \begin{tabular}{|c|} 
Before \\
treatment
\end{tabular} & 3 & 6 & 12 & $\begin{array}{c}\text { Before } \\
\text { treatment }\end{array}$ & 3 & 6 & 12 & $\begin{array}{c}\text { Before } \\
\text { treatment }\end{array}$ & 3 & 6 & 12 \\
\hline & & \multicolumn{4}{|c|}{ Number of cases } & \multicolumn{4}{|c|}{ Number of cases } & \multicolumn{4}{|c|}{ Number of cases } \\
\hline 1. & $\begin{array}{c}\text { Pain } \\
\text { in the feet }\end{array}$ & 14 & 10 & 8 & 10 & 10 & 6 & 6 & 6 & 12 & 6 & 4 & 4 \\
\hline 2. & $\begin{array}{c}\text { Pain } \\
\text { in the low leg }\end{array}$ & 4 & 2 & 2 & 2 & 4 & 2 & 2 & 2 & 4 & 0 & 0 & 0 \\
\hline 3. & Cramps & 2 & 0 & 2 & 2 & 2 & 0 & 0 & 0 & 0 & 0 & 0 & 0 \\
\hline 4. & $\begin{array}{c}\text { Rapid } \\
\text { fatigability }\end{array}$ & 16 & 6 & 8 & 8 & 12 & 2 & 4 & 4 & 14 & 4 & 4 & 4 \\
\hline
\end{tabular}

The use of plaster casts in combination with complex physiotherapeutic treatment in subgroup A of the main group was more effective than in the control group due to the alternation of the static rest phase and dynamic work of the muscles, which takes part in the 
formation of the foot arches. The best result was achieved in patients of subgroup B of the main group. Elimination of clinical symptoms was achieved through the combined use of plaster casts and silicone pelottes, which reduce pressure on soft tissues and contribute to local correction of associated foot deformities. Also, positive results were obtained in patients of the control group after the use of complex physiotherapeutic treatment, but the indicators were slightly worse.

Radiological parameters after orthopedic treatment for a period of 12 months changed as follows: in subgroup A of the main group, radiological parameters after treatment indicated a positive trend. Before treatment, the scaphoid angle was $157,4^{\circ}\left( \pm 1,5^{\circ}\right)$. After 12 months of observation, it was $155.8^{\circ}$. Correction of the medial arch was achieved by creating optimal congruence in the talo-navicular joint. The pain syndrome was relieved due to decreased load on the tendon of the posterior tibial muscle. The most significant changes in scaphoid angle indicators were noted in subgroup B of the main group. The scaphoid angle decreased from $157.2^{\circ}\left( \pm 1.6^{\circ}\right)$ to $154.5^{\circ}\left( \pm 1.3^{\circ}\right)$. This is explained by the correction of not only the medial arch, but also the associated deformities in different parts of the foot, which has a positive effect on its architectonics.

The scaphoid angle value in the control group did not change significantly during 12 months of observation.

At the second stage, physiotherapeutic treatment in combination with biogenic stimulants was used to improve hemodynamics, muscle tone of the lower leg and foot.

After 12 months of observation in the main group there was no pain syndrome under dynamic loads in $86.9 \%$ of cases. In $8.6 \%$ of cases, pain syndrome occurred with significant physical activity. In $4.3 \%$ of cases, pain syndrome was observed during short-term activity.

In the control group, there was no pain syndrome in $9.5 \%$ of cases. In $42.8 \%$ of cases, pain syndrome occurred with minor physical activity. In $19.0 \%$ of cases, pain was noted during short-term activity. In $14.3 \%$ of cases, pain occurred when the patient begins to walk.

The indicators of X-ray examination after treatment changed as follows: after 12 months, the scaphoid angle in the main group decreased from $155.8^{\circ}\left( \pm 2.1^{\circ}\right)$ to $151.2^{\circ}\left( \pm 2.5^{\circ}\right)$. In the control group, the radiological parameters did not change significantly: before treatment $-156.2^{\circ}\left( \pm 2.4^{\circ}\right)$ and after treatment $-155.4^{\circ}\left( \pm 2.2^{\circ}\right)$.

The average indicators of quantitative changes in the cross-section of the lower leg and foot muscles after the use of biostimulants for 12 months are presented in Table 3. 
Table 3. Changes in the cross section of the lower leg and foot muscles according to the results of ultrasound at the second stage of treatment

\begin{tabular}{|c|c|c|c|c|c|c|c|c|c|}
\hline \multirow[t]{3}{*}{ № } & \multirow{3}{*}{$\begin{array}{l}\text { Muscles being } \\
\text { examined } \\
\text { (section in } \mathbf{m m} \text { ) }\end{array}$} & \multicolumn{4}{|c|}{$\begin{array}{c}\text { Control group } n=42 \\
\qquad \pm m\end{array}$} & \multicolumn{4}{|c|}{$\begin{array}{c}\text { Main group } n=46 \\
M \pm m\end{array}$} \\
\hline & & \multirow{2}{*}{$\begin{array}{c}\text { Before } \\
\text { treatment }\end{array}$} & \multicolumn{3}{|c|}{ After treatment } & \multirow{2}{*}{$\mid \begin{array}{c}\text { Before } \\
\text { treatment }\end{array}$} & \multicolumn{3}{|c|}{ After treatment } \\
\hline & & & 3 & 6 & 12 & & 3 & 6 & 12 \\
\hline 1. & \begin{tabular}{|l}
$\begin{array}{l}\text { Flexor digitorum } \\
\text { longus }\end{array}$ \\
\end{tabular} & $\begin{array}{c}8,3 \\
\pm 0,3 \\
\end{array}$ & $\begin{array}{r}8,3 \\
\pm 0,2 \\
\end{array}$ & $\begin{array}{r}8,3 \\
\pm 0,3 \\
\end{array}$ & $\begin{array}{r}8,5 \\
\pm 0,1 \\
\end{array}$ & $\begin{array}{r}8,3 \\
\pm 0,5 \\
\end{array}$ & $\begin{array}{r}8,9 \\
\pm 0,5 \\
\end{array}$ & $\begin{array}{c}8,9 \\
\pm 0,5 \\
\end{array}$ & $\begin{array}{r}9,3 \\
\pm 0,4 \\
\end{array}$ \\
\hline 2. & $\begin{array}{l}\text { Extensor digitorum } \\
\text { longus }\end{array}$ & $\begin{array}{c}7,4 \\
\pm 0,5 \\
\end{array}$ & $\begin{array}{r}7,5 \\
\pm 0,4 \\
\end{array}$ & $\begin{array}{r}7,7 \\
\pm 0,3 \\
\end{array}$ & $\begin{array}{r}7,6 \\
\pm 0,4 \\
\end{array}$ & $\begin{array}{r}7,4 \\
\pm 0,2 \\
\end{array}$ & $\begin{array}{r}7,9 \\
\pm 0,3 \\
\end{array}$ & $\begin{array}{c}8,2 \\
\pm 0,5\end{array}$ & $\begin{array}{r}8,4 \\
\pm 0,2 \\
\end{array}$ \\
\hline 3. & $\begin{array}{l}\text { Extensor hallucis } \\
\text { brevis, }\end{array}$ & $\begin{array}{r}4,6 \\
\pm 0,2 \\
\end{array}$ & $\begin{array}{c}4,8 \\
\pm 0,3 \\
\end{array}$ & $\begin{array}{r}4,8 \\
\pm 0,1 \\
\end{array}$ & $\begin{array}{r}4,9 \\
\pm 0,3 \\
\end{array}$ & $\begin{array}{r}4,6 \\
\pm 0,4 \\
\end{array}$ & $\begin{array}{c}5,4 \\
\pm 0,1 \\
\end{array}$ & $\begin{array}{c}5,2 \\
\pm 0,4 \\
\end{array}$ & $\begin{array}{r}5,5 \\
\pm 0,1 \\
\end{array}$ \\
\hline 4. & $\begin{array}{l}\text { Flexor hallucis } \\
\text { brevis }\end{array}$ & $\begin{array}{l}5,81 \\
\pm 0,1 \\
\end{array}$ & $\begin{array}{r}6,0 \\
\pm 0,2 \\
\end{array}$ & $\begin{array}{r}5,9 \\
\pm 0,3 \\
\end{array}$ & $\begin{array}{c}5,9 \\
\pm 0,1 \\
\end{array}$ & $\begin{array}{r}5,9 \\
\pm 0,3 \\
\end{array}$ & $\begin{array}{c}6,5 \\
\pm 0,5 \\
\end{array}$ & $\begin{array}{c}6,8 \\
\pm 0,4 \\
\end{array}$ & $\begin{array}{r}6,9 \\
\pm 0,3 \\
\end{array}$ \\
\hline 5 . & Abductor hallucis, & $\begin{array}{c}5,7 \\
\pm 0,1\end{array}$ & $\begin{array}{c}5,9 \\
\pm 0,3\end{array}$ & $\begin{array}{c}5,8 \\
\pm 0,2\end{array}$ & $\begin{array}{c}5,8 \\
\pm 0,3\end{array}$ & $\begin{array}{c}5,7 \\
\pm 0,4\end{array}$ & $\begin{array}{c}6,1 \\
\pm 0,3\end{array}$ & $\begin{array}{c}6,4 \\
\pm 0,2\end{array}$ & $\begin{array}{c}6,8 \\
\pm 0,1\end{array}$ \\
\hline 6. & Tibialis posterior & $\begin{array}{r}7,6 \\
\pm 0,3 \\
\end{array}$ & $\begin{array}{r}8,5 \\
\pm 0,2 \\
\end{array}$ & $\begin{array}{r}8,2 \\
\pm 0,4 \\
\end{array}$ & $\begin{array}{c}8,2 \\
\pm 0,1 \\
\end{array}$ & $\begin{array}{r}7,9 \\
\pm 0,3 \\
\end{array}$ & $\begin{array}{r}9,9 \\
\pm 0,2 \\
\end{array}$ & $\begin{array}{c}9,7 \\
\pm 0,4 \\
\end{array}$ & $\begin{array}{r}9,8 \\
\pm 0,3 \\
\end{array}$ \\
\hline
\end{tabular}

In assessing the structural condition of the muscles of the lower leg and foot, which affect the formation of the medial arch, after the use of biostimulants in the main group, the quantitative indicators of muscle section were increased. In the control group, these indicators were less significant.

Analyzing the results of RVG of the lower extremities, we can note a positive effect after treatment in the main group after 12 months of observation. There was an increased blood filling of the tissues in studied segments, normalization of the estimate indicators of the great vessel's elasticity and the venous bed tone, as well as decreased peripheral vascular resistance. The RVG curve has a convex shape (Fig. 7).

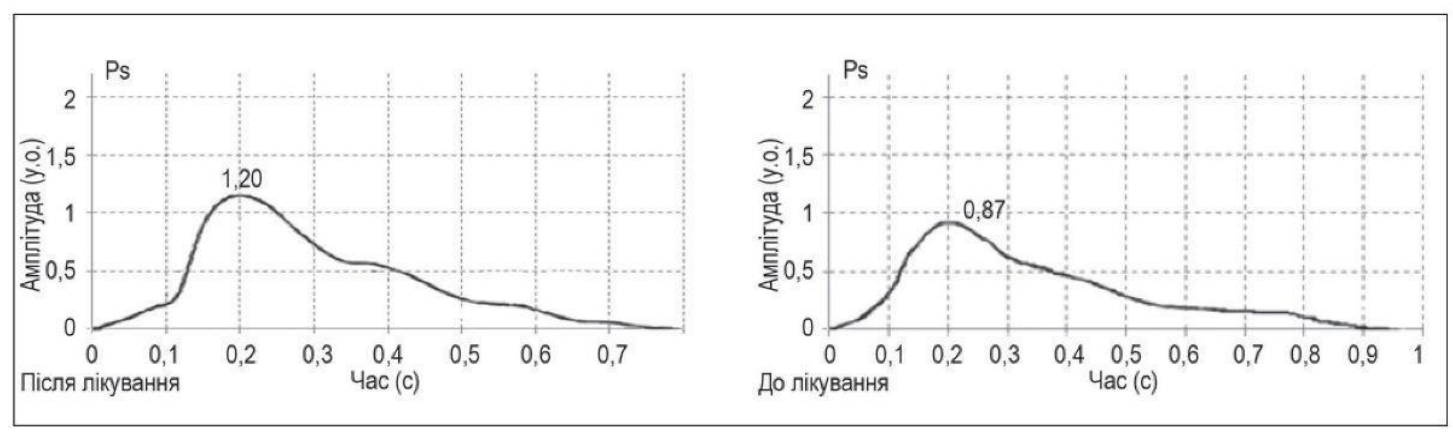

a

b

Figure 7. Changes in rheosystolic index values in the main group, a (after treatment), $b$ (before treatment) 
Analysis of the RVG results in the control group demonstrates regression of indicators, as follows: a decreased tissue blood filling, vasoconstriction of the main arteries and peripheral vessels, impaired venous outflow. The descending part of the RVG curve has a smooth shape, which is interpreted as a weakly positive dynamic of the peripheral blood supply to the lower extremities after 12 months of observation (Fig. 8)

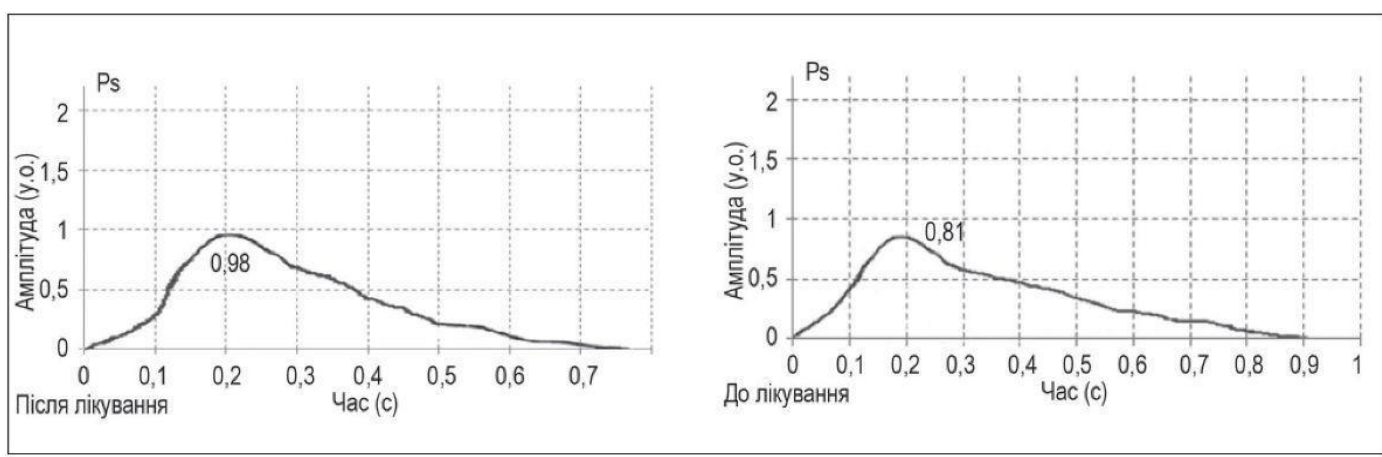

a

b

Figure 8. Changes in rheosystolic index values in the control group, a (after treatment), $b$ (before treatment)

Thus, the application of the conservative treatment method developed by us, allowed us to obtain positive results in the treatment of RLF with I-II severity degree. At the first stage, the greatest efficiency was achieved in patients who used serial casting in combination with silicone pelottes. This allowed to increase the medial arch of the foot and reduce clinical manifestations due to mild correction of the arch and associated deformities.

At the second stage, the hemodynamics and tone of the muscles affecting the formation of the foot arch were improved. The use of placenta extract improved the blood supply to the muscles, thereby increasing their contractility.

\section{Conclusions}

Algorithms for conservative treatment of LF have been developed, depending on the severity, nature of deformity, hemodynamic disorders and muscle tone in the low leg and foot.

In the treatment of LF with severe pain, the use of serial casting in combination with silicone pelottes for associated deformities in different parts of the foot is effective.

In case of hemodynamics disorders, muscle tone participating in the formation of the foot arch, as well as to prevent regression of the achieved results, the use of biostimulants is effective. 
The author declares no conflicts of interest. The article was published without any financial support.

\section{References}

1. Ivanova G.E., Skvortsov D.V. Objective clinical analysis of gait: overview. Bulletin of restorative medicine. 2015; vol.68, no 4, pp.59-66.

2. Craid C. L. (1993) Foot and leg problems. Pediatr. rev., vol. 14, no 10, pp. 395-400.

3. Zatravkina T., Rubashkin S., Dohov M. (2018) Flatfeet in children: etiopathogenesis and diagnostics: review. Saratov Journal of Medical Scientific Research, vol. 14, no 3, pp. 389-395.9-113.

4. Shulga O.V., (2020) Classification and mechanism of longitudinal flatfoot formation in children. Pediatric surgery Ukraine, vol. 66, no 1, pp. 58-63.

5. Shevelyova I., Dubovihin A. (2018) Problems of conservative treatment of patients with flatfeet. Kazan Medical Journal, vol. 99, no. 4, pp.665 - 669 DOI: 10. 17816/KMJ2018 665.

6. MacKenzie J., Keith A., Margaret A. (2012) The efficacy of nonsurgical interventions for pediatric flexible flat foot: a critical review. // A.Jane MacKenzie, K.Rome, A. M. Evans //J. Pediatric Orthopaedics, vol. 32, no 8, pp. 830-834, doi: 10.1097/BPO.0b013e3182648c95.

7. Epishev, V. (Epishev, Vitaly); Yakovleva, G (Yakovleva, Galina); Fedorova, K (Fedorova, Kristina) (2018) Individual silicone insol design and assessment of effectiveness. Menerva ortopedica e traumatologica, vol. 69, no 1, pp. 55-59.

8. Carr Jb, Yang S, Lather LA. (2016) Pediatric Pes Planus: a Stateof-the-Art Review. Pediatrics, 137 (3): e20151230.

9. Gromova O.A. (2011) World experience in the use of drugs from the human placenta: the results of clinical and experimental studies: review. Plastic surgery and cosmetology, no 3, pp. 385-576.

10. Dem'yan Yu.Yu., Guk.Yu.M. (2017) Flexible flat-valgus deformity of the feet in children with hypermobility of the joints. Terminology, clinical and radiological features. Bulletin of orthopedics, traumatology and prosthetics, no 4, pp.10-19. 